\title{
COVID-19: a basic approach to understanding potential treatments
}

\author{
Carla Cedillo-Alvarez, ${ }^{1}$ Itzell A. Gallardo-Ortiz, ${ }^{2}$ Luis T. López, ${ }^{3}$ Sergio Montes ${ }^{3}$ and
} Nayeli Páez-Martínez *

${ }^{1}$ Research Section, Escuela Militar de Medicina, Secretaría de la Defensa Nacional, Mexico City; ${ }^{2}$ Biomedical Research Unit, Iztacala Faculty of Higher Studies, Universidad Nacional Autónoma de México, State of Mexico; ${ }^{3}$ Neurochemistry Department, Instituto Nacional de Neurología y Neurocirugía, Mexico City; ${ }^{4}$ Post-degree and Research Section, Higher School of Medicine, Instituto Politécnico Nacional, Mexico City. Mexico

\begin{abstract}
SARS-COV-2 virus has been identified as the causative agent of the COVID-19 pandemic. Even when no standard treatment is available, antivirals such as remdesivir and other drugs such as chloroquine and ivermectin, which interfere with viral replication, have been assayed. Some strategies aimed at reducing immune mechanisms, such as the use of tocilizumab and natural antioxidants, have also been tested. The use of drugs related to the renin-angiotensin system has been controversial. Pathogenicity mechanisms, as well as controlled treatments, still have to be studied in detail in order to propose a viable therapeutic option that prevents the entry and replication of the virus or enhances the host immune system.
\end{abstract}

KEY WORDS: Covid-19. Pharmacological treatments. Renin-angiotensin system.

\section{COVID-19: enfoque básico para entender sus tratamientos}

\section{Resumen}

El virus SARS-CoV-2 ha sido identificado como el agente patológico causante de la pandemia de COVID-19. Aun cuando no se cuenta con un tratamiento estándar, se han probado antivirales como remdesivir y otros fármacos como cloroquina e ivermectina, que interfieren con la replicación del virus. También se han intentado algunas estrategias encaminadas a disminuir los mecanismos inmunitarios, como el uso de tocilizumab y antioxidantes naturales. Los fármacos relacionados con el sistema renina-angiotensina han resultado controversiales. Aún se debe estudiar con detalle los mecanismos de patogenicidad, así como los tratamientos controlados para proponer alguna opción terapéutica viable que evite la entrada y replicación del virus o que aumente los sistemas inmunitarios del huésped.

PALABRAS CLAVE: COVID-19. Tratamientos farmacológicos. Sistema renina-angiotensina.

\section{Possible therapeutic interventions for SARS-CoV-2 infection}

A wide variety of drugs have been used in the fight to counteract the emerging disease caused by
SARS-CoV-2; however, a standard treatment is not yet available.

Treatment proposals address different aspects:

- Virus entry into cells.

- Virus replication.
Correspondence:

*Nayeli Páez-Martínez

E-mail: nayepam @yahoo.com.mx
Gac Med Mex. 2020;156:570-575

Contents available at PubMed

www.gacetamedicademexico.com

0016-3813/@ 20xx Academia Nacional de Medicina de México, A.C.. Published by Permanyer. This is an open access article under the CC BY-NC-ND license (http://creativecommons.org/licenses/by-nc-nd/4.0/). 
- Reinforcement of immunity and prevention of exacerbated inflammation.

- Control of complications.

Numerous trials have been conducted looking for treatments or drug combinations to achieve recovery or reduce progression to severe forms of the disease. In this review, some of the most important proposals are described.

\section{Remdesivir}

Remdesivir is an adenosine analogue, and therefore it reduces viral RNA production. ${ }^{1}$ Its use for COVID-19 treatment is not yet approved, although several experimental studies are undergoing. In in vitro studies, remdesivir effectiveness against SARS-CoV-2 was observed. In experimental animals, remdesivir reduced pulmonary hemorrhage and the number of viral RNA copies. Preliminary studies on humans suggest that $70 \%$ of patients treated with this antiviral achieved improvement, including those with assisted ventilation. A non-controlled multicenter analysis used remdesivir, $200 \mathrm{mg}$ on the first day and then $100 \mathrm{mg} /$ day for nine days; out of 53 patients who received the drug, 36 showed clinical improvement $(68 \%) .{ }^{2}$ In another multicenter, randomized, double-blind, placebo controlled study, 237 patients were included; the use of remdesivir was not associated with clinical improvement in comparison with the control group. In addition, more adverse effects were reported in the group that received the drug. ${ }^{3}$ The results of these investigations suggest that protocols with a larger number of patients are required in order to assess the benefits the drug might offer in terms of time to clinical improvement.

\section{Ribavirin, lopinavir and ritonavir}

Ribavirin is a synthetic guanosine nucleoside that interferes with mRNA synthesis. In turn, lopinavir is a protease inhibitor that when co-administered with lowdose ritonavir significantly improves its pharmacokinetic properties and enhances its activity against HIV-1 protease. . $^{4,5}$

In a study carried out in 75 patients with severe acute respiratory syndrome, a reduction in mortality $(2.3 \%)$ and intubation $(0 \%)$ rates was observed in patients initially treated with lopinavir/ritonavir 400/100 mg every 12 hours for 14 days. ${ }^{6}$ In another investigation of 199 patients with SARS-CoV-2 infection, 99 patients were administered lopinavir/ritonavir and standard therapy and compared with a control group that received only standard therapy; the results showed no difference between groups in time to patient improvement. ${ }^{7}$

In another analysis of COVID-19 patients, 400/100 $\mathrm{mg}$ of lopinavir/ritonavir were administered every 12 hours to one group, while another received an additional $400 \mathrm{mg}$ of ribavirin every 12 hours and three interferon doses of $8 \times 10^{6} \mathrm{IU}$ on alternate days. The results indicated that the triple antiviral therapy was safe and superior to lopinavir/ritonavir monotherapy in terms of disease duration and hospital stay days. ${ }^{8}$ Currently, studies are underway to determine the efficacy of different doses of rivavirine, as monotherapy or in combination with other drugs, in the management of COVID-19. ${ }^{9}$

\section{Azithromycin}

Azithromycin is a macrolide antibiotic whose mechanism of action is based on its reversible binding to bacterial ribosome 50 s subunit, thus preventing translocation. ${ }^{10}$ This drug has also shown anti-inflammatory and immunomodulatory properties, which has generated interest on its use in viral infections. Reports show a decrease in neutrophil counts and interleukins (IL) $8,6,1 \beta$, tumor necrosis factor $\alpha$, eosinophil cationic protein and metalloproteinase 9 concentration. ${ }^{11}$ These data suggest that azithromycin might decrease the pro-inflammatory cytokine cascade that is characteristic of COVID-19. Azithromycin also creates an unfavorable environment for viral replication. ${ }^{12}$ Azithromycin administration is started with $500 \mathrm{mg}$ orally on the first day, followed by $250 \mathrm{mg} /$ day for two to five days, according to medical judgment and patient preexisting conditions. ${ }^{13}$ Other authors evaluated viral loads in patients with COVID-19 after receiving hydroxychloroquine and azithromycin; they concluded that this drug combination produces viral elimination with higher efficacy. ${ }^{14}$ Currently, the National Institute of Allergy and Infectious Diseases of the United States is sponsoring a clinical trial to assess this drug in combination therapy with hydroxychloroquine..$^{15}$

\section{Chloroquine and hydroxychloroquine}

These drugs are considered to be able to change lysosomal pH and, therefore, to modify the activity of proteases and interfere with viral entry into cells. Chloroquine and hydroxychloroquine are also characterized for reducing pro-inflammatory interleukins, particularly IL-6, and thus their action could also be 
beneficial in the "cytokine storm". ${ }^{16}$ Furthermore, both drugs, at low concentrations, were observed to be able to inhibit viral replication and reduce viral load in vitro and in human studies, respectively. However, as a disadvantage, the use of chloroquine and hydroxychloroquine has been found to cause cardiotoxic effects, a particularly important effect that must be considered. ${ }^{17}$

\section{Ivermectin}

In vitro studies of Vero/hSLAM cells infected with SARS-CoV-2 and treated with ivermectin at a concentration of $5 \mu \mathrm{M}$ showed an almost absolute reduction of viral RNA; in addition, no toxicity associated with ivermectin was observed at the evaluated concentration. ${ }^{18}$

Ivermectin mechanism of action is still unknown; however, it is believed that it inhibits importin $\alpha / \beta 1$ and nuclear proteins of the virus and the host. ${ }^{12}$ The dose varies according to some criteria and it can be $12 \mathrm{mg}$ in a single oral dose or $12 \mathrm{mg}$ orally for two days. Several countries are using ivermectin in first-line treatments to combat the disease, as, for example, the Dominican Republic, Bolivia, and Peru. However, conducting further studies is considered appropriate in order to further evaluate its effectiveness as antiviral. ${ }^{19}$

\section{Tocilizumab}

This drug is a humanized monoclonal antibody that antagonizes IL-6 receptor. ${ }^{20,21}$ Currently, numerous clinical trials are underway to assess the use of tocilizumab in the treatment of SARS-CoV-2 infection. ${ }^{22}$ An investigation carried out in China with 21 patients reported that the addition of 4 to $8 \mathrm{mg} / \mathrm{kg}$ of tocilizum$a b$ to standard therapy produced clinical improvement, the ground-glass opacity pattern on computed tomography decreased after administration of the drug; 15 out of 20 patients required less supplemental oxygen and one patient did not require it. ${ }^{23}$ However, this study was not controlled, and the number of analyzed patients is not enough to formulate further inferences, and more research is therefore required to assess tocilizumab efficacy.

\section{Vitamin C}

Vitamin C possesses antioxidant capacity owing to the donation of an electron to the lipid radical, which stops lipid peroxidation self-perpetuating reaction; subsequently, vitamin $\mathrm{C}$ is transformed into two molecules, the ascorbate radical and dehydroascorbate; the latter is transformed back into ascorbate by the action of an oxidoreductase. ${ }^{24}$ Vitamin $\mathrm{C}$ recommended daily dose is 90 and $75 \mathrm{mg} /$ day in men and women, respectively, without special requirements. Viral infections are known to generate large amounts of oxygen free radicals; vitamin $C$ is used to neutralize this oxidative stress. ${ }^{25,26}$ In addition, vitamin $\mathrm{C}$ reduces inflammation by stimulating the production of anti-inflammatory cytokines and interferon, and it is therefore attributed a direct antiviral effect, ${ }^{27-29}$ hence its probable therapeutic usefulness in COVID-19 is considered. ${ }^{30}$

A randomized controlled clinical trial was recently carried out: CITRIS-ALI, in hospitalized patients who were administered a high dose of vitamin $\mathrm{C}$ by infusion (50 mg/kg every six hours for 96 hours). Although no significant differences were identified in the Sequential Organ Failure (SOFA) scale score or improvement in inflammation or vascular damage biomarkers (C-reactive protein and thrombomodulin, respectively), patients treated with vitamin $\mathrm{C}$ were found to require fewer days of intensive therapy and, in general, hospital stay. ${ }^{31,32}$ High doses of vitamin $C$ behave as pro-oxidants, which is why some studies suggest that small doses may have greater benefit. ${ }^{33}$ In COVID-19, the role of vitamin $C$ as an adjuvant treatment is still uncertain.

\section{Vitamin D}

Vitamin $D$ is photosynthesized in the skin from 7-dehydrocholesterol. ${ }^{34}$ In addition to other functions, vitamin D active form (calcitriol) plays an immunomodulatory role, increasing innate immune response and inhibiting adaptive immune response. ${ }^{35}$ In a retrospective multicenter study of 212 cases, low levels of vitamin D were found in critically-ill COVID-19 patients, with an association with clinical outcome being reported. ${ }^{36}$ The main cause of vitamin $D$ deficiency is inadequate exposure to sunlight, ${ }^{37,38}$ which has been suggested as a cause of the severity of responses to SARS-CoV-2-associated infection and mortality in Europe, together with inadequate intake of the vitamin. ${ }^{39,40}$ These data suggest that supplementation with vitamin D can be part of the therapeutic and prophylactic intervention in COVID-19. ${ }^{41}$

\section{Treatments related to the renin- angiotensin system}

The role of drugs that inhibit the renin-angiotensin system, such as angiotensin-converting enzyme 


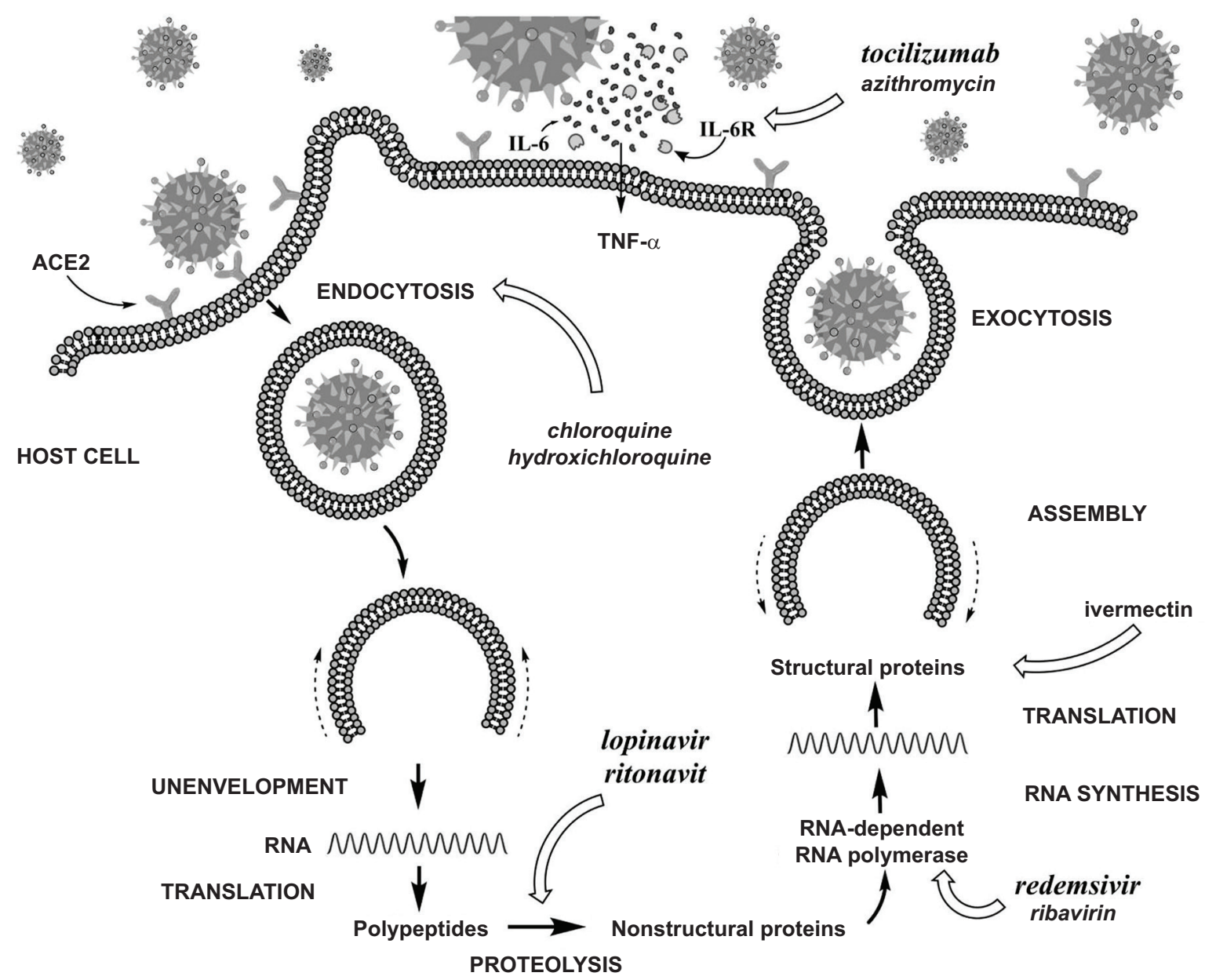

Figure 1. Proposed COVID-19 treatments. Probable sites of action of some drugs experimentally and clinically used against SARS-CoV-2 are shown. Chloroquine and hydroxychloroquine inhibit viral internalization and endocytosis; in addition, they have an immunomodulatory effect on the host. Azithromycin and tocilizumab inhibit IL-6 receptors activation and signaling pathways, which decreases macrophages and neutrophils chemoattraction. Lopinavir and ritonavir inhibit the formation of nonstructural proteins through the process of viral replication in 3-chymotrypsin-like protease. Remdesivir and ribavirin inhibit RNA-dependent RNA polymerase (RdRp) synthesis. In experimental studies, ivermectin inhibits the synthesis of structural proteins that are necessary for viral capsid assembly.

inhibitors (ACEI) and angiotensin II receptor blockers (ARBs) is controversial in the context of the COVID-19 pandemic. On one hand, there is information that shows that continuity of treatment with ACEI or ARB reduces morbidity and mortality in patients with COVID-19. ${ }^{42}$ In a systematic review that included 12 articles with more than 19,000 cases of COVID-19, exposure to ACEls or ARBs was reported not to be associated with a higher risk of COVID-19 infection or higher risk of serious infection or mortality; on the contrary, exposure to ACEls or ARBs was associated with a lower risk of mortality when the results were compared with those obtained in patients medicated with other antihypertensives. ${ }^{43}$ Mehta et al. concluded that there is no significant association between the use of ACEls or ARBs and COVID-19 test positivity.
Together, all these data support the notion of not discontinuing ACEls or ARBs in the context of the COVID-19 pandemic. ${ }^{44}$ In addition, several trials are currently underway to assess the effect of the administration of said antagonists for the treatment of patients with COVID-19. ${ }^{42}$

In contrast, recent cohort studies from Wuhan, China, suggest that the worst outcomes appear to be more common in patients with hypertension and diabetes, possibly due to angiotensin-converting enzyme 2 (ACE2) overexpression in alveolar epithelial cells owing to the treatment with ACEls or ARBs. In investigations with animals, ARAs and ACEls increased the expression of ACE2, SARS-CoV-2 access site, which generated concerns about whether these drugs increase COVID-19-associated morbidity and mortality. ${ }^{45}$ 
It is important to note that a careful search for data in the literature does not support this association. ${ }^{46}$

Soluble ACE2, not associated with the membrane, is enzymatically active and partially inhibits viral entry into target cells. A phase II clinical trial was recently reported in Europe, in which clinical-grade soluble human ACE2 is being tested to block SARS-CoV-2 infection. ${ }^{42}$ In fact, some structural variations of human ACE2 have been described, which is characterized by its low affinity to viral spike protein. The above data open possibilities for ACE2 protective implications on viral entry ${ }^{47}$ (Figure 1).

\section{Conclusions}

SARS-CoV-2 coronavirus infection spread all over the world in very few months. By the publication date of this manuscript, there was not yet a globally recommended drug available for treating the disease. Undoubtedly, scientific advances have led to proposing several drugs and vaccines to fight the virus. SARS-CoV-2 transmission in humans brings along a reflection on our coexistence with wildlife, our eating habits, and the care of our health in general.

\section{Acknowledgements}

We are deeply grateful to Dr. Ethel Rubinstein Malamud for her invaluable support in the preparation of this manuscript.

\section{Conflicts of interest}

The authors declare that they have no conflicts of interest.

\section{Funding}

The work was carried out with the support of the SIP-IPN projects, of Instituto Nacional de Psiquiatría "Dr. Ramón de la Fuente Muñiz" and Instituto Nacional de Neurología y Neurocirugía "Dr. Manuel Velasco Suarez", as well as Universidad Nacional Autónoma de México DGAPA, PAPIIT IN226819 projects.

\section{Ethical disclosures}

Protection of human and animal subjects. The authors declare that no experiments were performed on humans or animals for this research.
Confidentiality of data. The authors declare that no patient data appear in this article.

Right to privacy and informed consent. The authors declare that no patient data appear in this article.

\section{References}

1. DrugBank [website]. Canada: Remdesivir; 2019 [Updated Jan 14,2020]. [Accessed May 31, 2020]. Available at: https://www.drugbank.ca/drugs/ DB14761\#reference-A191379

2. Grein J, Ohmagari N, Shin D, Diaz G, Asperges E, Castagna A, et al. Compassionate use of remdesivir for patients with severe Covid-19. N Engl J Med. 2020;382:2327-2336.

3. Wang Y, Zhang D, Du G, Du R, Zhao J, Jin Y, et al. Remdesivir in adults with severe COVID-19: a randomised, double-blind, placebo-controlled, multicentre trial. Lancet. 2020;395:1569-1578.

4. DrugBank [website]. Canada: Ribavirin; 2005 [Updated Jan 14, 2020]. [Accessed May 31, 2020]. Available at: https://go.drugbank.com/drugs/ DB00811

5. Cvetkovic RS, Goa KL. Lopinavir/ritonavir: a review of its use in the management of HIV infection. Drugs. 2003;63:769-802.

6. Chan KS, Lai ST, Chu CM, Tsui E, Tam CY, Wong MM, et al. Treatment of severe acute respiratory syndrome with lopinavir/ritonavir: a multicentre retrospective matched cohort study. Hong Kong Med J. 2003; 9:399-406.

7. Cao B, Wang Y, Wen D, Liu W, Wang J, Fan G, et al. A trial of lopinavir-ritonavir in adults hospitalized with severe Covid-19. N Engl J Med. 2020;382:1787-1799.

8. Hung IF, Lung KC, Tso EY, Liu R, Chung TW, Chu MY, et al. Triple combination of interferon beta-1b, lopinavir-ritonavir, and ribavirin in the treatment of patients admitted to hospital with COVID-19: an open-label, randomised, phase 2 trial. Lancet. 2020;395:1695-1704.

9. Khalili JS, Zhu H, Mak NSA, Yan Y, Zhu Y. Novel coronavirus treatment with ribavirin: groundwork for an evaluation concerning COVID-19. J Med Virol. 2020;92:740-746.

10. Lorenzo-Fernández P, Moreno-González A, Leza-Cerro JC, Moro-Sánchez MA, Lizasoain-Hernández I. Antibióticos macrólidos y otros antibióticos. En: Velázquez, editor. Manual de farmacología básica y clínica. Mexico: Editorial Panamericana; 2018.

11. Zimmermann P, Ziesenitz VC, Curtis N, Ritz N. The immunomodulatory effects of macrolides-a systematic review of the underlying mechanisms. Front Immunol. 2018;9:302.

12. Choudhary R, Sharma AK. Potential use of hydroxychloroquine, ivermectin and azithromycin drugs in fighting COVID-19: trends, scope and relevance. New Microbes New Infect. 2020;35:100684.

13. Valentin F. Azithromycin and COVID-19 history and review. 2020

14. Gautret $P$, Lagier JC, Parola P, Hoang VT, Meddeb L, Mailhe M, et al. Hydroxychloroquine and azithromycin as a treatment of COVID-19: results of an open-label non-randomized clinical trial. Int $J$ Antimicrob Agents. 2020;56:105949.

15. National Institutes of Health [website]. USA: NIH begins clinical trial of hydroxychloroquine and azithromycin to treat COVID-19; 2020.

16. Wu R, Wang L, Kuo HD, Shannar A, Peter R, Chou PJ, et al. An update on current therapeutic drugs treating COVID-19. Curr Pharmacol Rep. 2020;1-15.

17. Sanders JM, Monogue ML, Jodlowski TZ, Cutrell JB. Pharmacologic treatments for coronavirus disease 2019 (COVID-19): a review. JAMA. 2020;323:1824-1836.

18. Caly L, Druce JD, Catton MG, Jans DA, Wagstaff KM. The FDA-approved drug ivermectin inhibits the replication of SARS-CoV-2 in vitro. Antiviral Res. 2020;178:104787.

19. Sharun K, Dhama K, Patel SK, Pathak M, Tiwari R, Singh BR, et al. Ivermectin, a new candidate therapeutic against SARS-CoV-2/COVID-19. Ann Clin Microbiol Antimicrob. 2020;19:23.

20. DrugBank [website]. Canada: Tocilizumab; 2008. [Updated Jan 14, 2020]. [Accessed May 07, 2020]. Available at: https://go.drugbank.com/ drugs/DB06273

21. Food and Drug Administration [website]. USA: FDA approved drug products: actemra tocilizumab intravenous or subcutaneous injection; 2013.

22. BMJ Best Practice [website]. Coronavirus disease 2019 (COVID-19). Emerging treatments. BMJ Best Practice; 2020. Available at: https:// bestpractice.bmj.com/topics/en-us/3000168/emergingtxs

23. Xu X, Han M, Li T, Sun W, Wang D, Fu B, et al. Effective treatment of severe COVID-19 patients with tocilizumab. Proc Natl Acad Sci U S A. 2020;117:10970-10975.

24. Nimse SB, Pal D. Free radicals, natural antioxidants, and their reaction mechanisms. RSC Advances. 2015;5:27986-8006. 
25. Schencking M, Vollbracht C, Weiss G, Lebert J, Biller A, Goyvaerts B, et al. Intravenous vitamin $C$ in the treatment of shingles: results of a multicenter prospective cohort study. Medical Sci Monit. 2012;18:CR215CR224.

26. Mikirova N, Hunninghake R. Effect of high dose vitamin C on Epstein-Barr viral infection. Medical Sci Monit. 2014;20:725-732.

27. Boretti A, Banik BK. Intravenous vitamin C for reduction of cytokines storm in acute respiratory distress syndrome. PharmaNutrition. 2020;12:100190.

28. Colunga-Biancatelli RML, Berrill M, Marik PE. The antiviral properties of vitamin C. Expert Rev Anti Infect Ther. 2020;18:99-101.

29. Kim MS, Kim DJ, Na CH, Shin BS. A study of intravenous administration of vitamin $C$ in the treatment of acute herpetic pain and postherpetic neuralgia. Ann Dermatol. 2016;28:677-683.

30. Cheng RZ. Can early and high intravenous dose of vitamin $C$ prevent and treat coronavirus disease 2019 (COVID-19)? Med Drug Discov. 2020;5:100028.

31. Hemilä $\mathrm{H}$, Chalker $\mathrm{E}$. Vitamin $\mathrm{C}$ can shorten the length of stay in the ICU: a meta-analysis. Nutrients. 2019;11:708.

32. Fowler AA, Truwit JD, Hite RD, Morris PE, DeWilde C, Priday A, et al Effect of vitamin $C$ infusion on organ failure and biomarkers of inflammation and vascular injury in patients with sepsis and severe acute respiratory failure: the CITRIS-ALI randomized clinical trial. JAMA 2019;322:1261-1270.

33. Hunt C, Chakravorty NK, Annan G, Habibzadeh N, Schorah CJ. The clinical effects of vitamin $C$ supplementation in elderly hospitalised patients with acute respiratory infections. Int J Vitam Nutr Res. 1994;64:212-219.

34. Ross AC, Taylor CL, Yaktine AL, del Valle HB. Dietary reference intakes for calcium and vitamin D. EE. UU.: National Academies Press; 2011.

35. Lagishetty V, Misharin AV, Liu NQ, Lisse TS, Chun RF, Ouyang Y, et al Vitamin $D$ deficiency in mice impairs colonic antibacterial activity and predisposes to colitis. Endocrinology. 2010;151:2423-2432.
36. Alipio M. Vitamin D supplementation could possibly improve clinical outcomes of patients infected with coronavirus-2019 (COVID-19). SSRN Electronic J. 2020.

37. Holick MF, Siris ES, Binkley N, Beard MK, Khan A, Katzer JT, et al. Prevalence of vitamin D inadequacy among postmenopausal North American women receiving osteoporosis therapy. J Clin Endocrinol Metab. 2005;90:3215-3224.

38. Moan J, Porojnicu AC, Dahlback A, Setlow RB. Addressing the health benefits and risks, involving vitamin D or skin cancer, of increased sun exposure. Proc Natl Acad Sci U S A. 2008;105:668-673.

39. Spiro A, Buttriss JL. Vitamin D: an overview of vitamin D status and intake in Europe. Nutr Bull. 2014;39:322-350.

40. Laird E, Rhodes J, Kenny RA. Vitamin D and Inflammation: potential implications for severity of Covid-19. Ir Med J. 2020;113:81-87.

41. Jakovac H. COVID-19 and vitamin D-is there a link and an opportunity for intervention? Am J Physiol Endocrinol Metab. 2020;318:E589.

42. Saavedra JM. COVID-19, angiotensin receptor blockers, and the brain. Cell Mol Neurobiol. 2020;40:667-674.

43. Zhang $X, Y u$ J, Pan LY, Jiang HY. ACEI/ARB use and risk of infection or severity or mortality of COVID-19: a systematic review and meta-analysis. Pharmacol Res. 2020;158:104927.

44. Mehta N, Kalra A, Nowacki AS, Anjewierden S, Han Z, Bhat P, et al. Association of use of angiotensin-converting enzyme inhibitors and angiotensin II receptor blockers with testing positive for coronavirus disease 2019 (COVID-19). JAMA Cardiol. 2020;5:1020-1026.

45. Kai H, Kai M. Interactions of coronaviruses with ACE2, angiotensin II, and RAS inhibitors-lessons from available evidence and insights into COVID-19. Hypertens Res. 2020;43:648-654.

46. Rico-Mesa JS, White A, Anderson AS. Outcomes in patients with COVID-19 infection taking ACEI/ARB. Curr Cardiol Rep. 2020;22:31.

47. Verdecchia P, Cavallini C, Spanevello A, Angeli F. The pivotal link between ACE2 deficiency and SARS-CoV-2 infection. Eur J Intern Med. 2020;76:14-20. 